\title{
EDUCATIONAL ACTIVITY OF TATAR INTELLECTUALS IN TURKEY IN THE FIRST HALF OF THE 20th CENTURY
}

\section{M.R. Gaynanova}

\author{
Sh. Marjani Institute of History of \\ the Tatarstan Academy of Sciences \\ Kazan, Russian Federation \\ mgaynanova@gmail.com
}

Istanbul and Kazan in the early twentieth century were the learning centers of the Turkic world, the centers of the formation of ethnic, national and Turkic selfconsciousness. There were close ideological and cultural ties between these cities, which were represented in the constant contacts of people and exchange of information through newspaper and magazine materials. It should be noted that the Tatar intellectuals who emigrated to Turkey had a great influence on the formation of the national selfimage of the Turks, on their development as a nation, on shaping Turkey as a secular state. Some of them were even in the inner circle of Ataturk, the first president of the Turkish Republic, worked as his advisers on cultural and political issues. Their authority and influence were significant not only in the political and administrative life of the country, but also in research and education. As the Turkish Republic has been formed, construction of national educational schools begins, newspapers and magazines are published with the purpose to grow the national self-consciousness of the Turks.

The report reveals the issue of the educational activities of Tatar intellectuals in Turkey in the first half of the 20th century.

Keywords: Turkey, tatar intellectuals, education, cultural ties.

For citation: Gaynanova M.R. Educational activity of Tatar intellectuals in Turkey in the first half of 20th century. Istoricheskaya etnologiya - Historical Ethnology, 2018, vol. 3, no. 2, pp. 267-274. DOI: 10.22378/he.2018-3-2.267-274

At the beginning of the $20^{\text {th }}$ century Istanbul and Kazan were the centers of education, bookishness and scholarship of the Turkic world, the centers of the formation of ethnic, national and Turkic self-consciousness. There were close ideological and cultural ties between the Tatars of Kazan and Istanbul, which were represented in the constant contacts of people and exchange of information through newspaper and magazine materials, as well as through literary works. Quite a lot of Tatar peasants in the late $19^{\text {th }}$ century emigrated to the Ottoman state, also a lot of the Tatar youth went there to study. A large wave of emigrants poured into Turkey, as the Turks were closer in blood and religion to the Tatar people. It is known that from the late $19^{\text {th }}$ century Tatars moved to the Ottoman Empire in the hope of starting a new life. This fact is mentioned in the works of Tatar writers. For example, the well-known writer Makhmut Galyau 
(1887-1938) writes about the mass departure of Tatar peasants in 1897 to Turkey in search of happiness and a new life in his novel "Haze" ("Bolganchyk yillar") [4, p. 216]. The resettlement of the Tatar population from the villages of the Volga region and the Urals was caused by the violent Christianization of Muslims after the defeat of Russia in the Crimean War. In 1890, a decree was issued by the Ministry of Foreign Affairs of Russia on the possibility of emigration of the Volga region and the Urals Muslim population abroad for religious reasons. In 1892, the consent of the Turkish Sultan Abdul Hamid II was received about the resettlement of several thousand Muslims from Russia; at the beginning of 1893 up to three thousand Turkic Tatars moved from the regions of the Volga and the Urals to Turkey. Being adherents of Islam, having a significant linguistic and ethnic and socio-cultural similarity, the Turkic Tatars were hospitably received by the Turkish authorities; the government allocated land, materials, and benefits to them [3, p. 50].

The well-known Tatar writer, the politician Gayaz Iskhaki, in his report on "The Present Situation of Turkic-Tatar Emigrants in Europe and Their Perspectives on the Future," read by him at the Muslim Community in 1934, writes that the Turkic Tatars, who arrived in Turkey before the revolution, almost all lived together, having organized one large settlement and completely did not lose their national life, and all of them are Turkish subjects. Our compatriots had a lot of authority in the cultural world of Turkey. In the Turkish universities many Turkic Tatars professors lectured, some of them even held rector positions, and all of them were highly respected in the scientific world. In the press, the Turkic Tatar journalists also occupied a significant position. For example, our compatriot Faizi [8] worked as the editor of the political department of the most widely spread government newspaper in Turkey Cumhuriyet [8]. It stands to mention that S. Maksudi published many of his articles there.

To be fair, it should be noted that the Tatars had every reason to consider those countries as the "second homeland," in the development of history, culture, and science of which they made a significant contribution [3, p. 49-50]. The Tatar intellectuals, emigrated after the October Revolution, settled in Turkey differently. In particular, the modern Turkish public notes the great importance in the cultural development of Turkey of such figures as Yu. Akchura, S. Maksudi [3, p. 50]. Several leaders of the Muslim peoples of the empire A. Agayev, Yu. Akchura, A. Huseyn-zade, and A. Ibragimov, having found themselves after the first Russian revolution abroad, organized a special Committee for Protection of the Rights of the Turkic Tatars in Russia in 1915. The purpose of the Committee was to raise the issue of national rights, including the self-determination of Muslim Turks in the Russian Empire and in the international arena [6, p. 111-112].

If you go back to the beginning of the $20^{\text {th }}$ century, in the Tatar madrasas of that period Turkish textbooks, magazines, books were brought from Istanbul, the Tatar intellectuals got acquainted with French novels, including their Turkish translations. Sadri Maksudi and Gayaz Iskhaki, as students of the Kazan 
Teachers School, read the works of prominent French philosophers and writers in Turkish and Russian. Therefore, Istanbul served as a guide to the world of knowledge for the Tatar youth.

Russian Muslims began to apply to Turkish educational institutions after the revolution in 1905. For example, it is known that in 1906 four young men from Kazan Tatars applied for admission to the University of Istanbul. In view of the fact that the charter of the university has not yet developed a clause on the conditions for the training of foreign students, it was impossible to satisfy their request. The bureaucratic obstacles were completely removed in 1908, since that time many young people from Russia began to study in educational institutions of Istanbul. After the Young Turk revolution in 1908, these young people began to establish their societies and communities. The first of them, the Society of Russian Muslim Students, was created in October 1908 by Kazan Tatars. Following them in early 1909, an Arab, Kurdish, Albanian student societies appeared in Istanbul [9, p. 100].

Tatar students who studied in higher educational institutions of Turkey also were a model to emulate for all the rest. They were distinguished by spirituality, the presence of certain ideals preparing themselves for the present and the future, working capacity, stability, and diligence. Fatikh Karimi has heard flattering reviews about them from the rectors of the Istanbul University and the Istanbul Pedagogical Institute [7, p. 414].

At the beginning of the twentieth century a whole wave of Tatar intellectuals, students, workers was in Turkey. Most of the Tatar figures settled in Istanbul and took part in the intellectual and political life of the Turkish state. Such were, for example, Musa Akgyetzade (1864-1923), Yusuf Akchura (18761935), Gabdrasit Ibragimov (1857-1944), Sadri Maksudi (1878-1957), Gayaz Iskhaki (1878-1954), Rashit Rahmati Arat (1900 -1964), Akdes Nigmati Kurat (1903-1971) and others. It should be noted that since the $19^{\text {th }}$ century the relations between the two peoples have become close due to the activities of I. Gasprinskiy and the Tarjeman newspaper. The language of the newspaper was understandable to all the Turkic speaking peoples of the Russian Empire and was close to the Ottoman language, which helped bring all the Turkic peoples closer together. All these figures gain authority in the social, scientific, and political life of Turkey. Tatar intellectuals work closely with magazines, newspapers and public organizations. Many of these figures were educated in Istanbul and some even stayed to live in the Ottoman Empire and later in the Turkish Republic.

Musa Akyegetzade is known in the Tatar literature as the first author of the realistic novel "Hisametdin Menla" (1886); in Turkey he is known for being one of the first economists who spoke with the dissemination of the ideas of Friedrich List (1789-1846) in the national economy of the Ottoman Empire. He has a special place in the Turkish history as the largest economist and also as a thinker who managed to create an economic system in which the achievements of the world economic science, as well as Islamic traditions, are synthesized; 
moreover, he is known as a popularizer of these achievements in the Ottoman Empire of the Young Turks. As for the life of Musa Akyegetzade, in 1884-1888 he lives in such cities as Kazan, Penza, Bakhchisaray (Crimea), works in the editorial office of the Tarjeman newspaper and in 1888, following I. Gasprinskiy's instruction, he leaves for Istanbul where he enters the Military Academy (Mekteb-i Mülkiye) which trains officials for state institutions. In 1891, upon graduating from the academy, he works in the administrative and civil service. In $1892 \mathrm{M}$. Akyegetzade began teaching at the Military College (Mekteb-i Erkân-1 Harbiye) where he held the position of a teacher of the Russian language and economy in the infantry and cavalry, the veterinary police classes, as well as in the upper classes on the general history. As a matter of fact, the first President of Turkey Mustafa Kemal Ataturk (1881-1938) studied at the same Military College from 1902 to 1905. In 1906-1908 M. Akyegetzade publishes the newspaper Metin. The newspaper issued on four pages highlighted political, social, economic and military problems. In total there are 32 issues [11, p. 574]. Due to the fact that the pages covered all the details of the economic crisis of the Ottoman Empire, the course of military operations and other acute problems were touched upon, the official authorities reacted negatively to the Metin newspaper and closed it.

Yusuf Akchura (1876-1935) is a graduate of the Political Science School at the Sorbonne, deputy of the Turkish parliament, adviser of the first president of Turkey, Ataturk, politician, political scientist, historian, who contributed not only to the creation of the national ideology of Turkey, but also to the formation of the Turkish nation as such. In 1883, when he was still a child, he and his mother came to Istanbul, where in 1895, upon graduating from school, he entered the Military School. After the 2nd year he participated in movements on Turkism and for that he was expelled from school and arrested. After that Yu. Akchura went to Paris to study, afterwards to Kazan. Returning in 1908 to Istanbul, Yu. Akchura organizes the society "Turk Dernegi" (December 25, 1908-1912) which unites all Turkic Muslims living in the Ottoman Empire and not only. Its main purpose is to spread the ideas of Turkism. The Society issued tracts, newspapers; meetings and speeches were organized [1, p. 229-232].

In 1911 the first issue of the magazine Türk Yurdu is published in Turkey ("Turkic Homeland") and the editor is the famous Tatar and Turkish figure Yusuf Akchura. The financial support for the issue of the magazine is provided by a prominent Tatar industrialist from Orenburg Makhmud Khusainov. From 1911 to 1918. 14 volumes, 161 issues of the journal were published. According to $\mathrm{Yu}$. Akchura himself, the main purpose of the publication was to acquaint the scientists of the Turkic world, their work on common goals and polemic on the pages of the magazine. According to the statistical calculation of the Japanese historian Masami Arai, the heading "News of the Turkic World" of the magazine Turk Yurdu was halfway devoted to Central Asia and Islam in the Russian Empire, the second half concerned the internal situation of the Ottoman Empire; $43 \%$ of articles were written by Turks of Russian origin (page 194, Islam in the 
Tatar world). Thus, Tatar intellectuals bring Ottoman knowledge on the situation, the lives of Russian Muslims. The pages of the publication give an idea of education, news about the life of Russian Turks. The magazine Turk Yurdu headed by Yusuf Akchura propagandized the "Tatar model" of modernization on its pages. After the Young Turk revolution, the interest in the Muslims of Russia, their lives and views is arisen [5, p. 194].

Outstanding and recognized throughout the Muslim world, the Tatar religious thinker-reformer and public figure Musa Bigiev (1875-1949) was accepted to the engineering school in Istanbul in 1901. In this same city the fateful meeting of Musa Bigiev with his fellow countryman Musa Akyegetzade (18641923), who taught Russian language and economics at the Military College ("Mekteb-i Erkân-1 Harbiye") since 1892, took place. M. Akyegetzade urged his young compatriot to continue studying the Muslim sciences. However, Musa Bigiev was not satisfied with the Ottoman system of religious education. Therefore, in search of knowledge, he went on an educational tour to the Muslim lands of the Middle East and India [10, p. 18]. After a long distance, having visited many countries and having gained numerous friends among the religious and scientific intellectuals, Musa Bigiev returned to Russia in 1904. In Russia Musa Bigiev began active work in Islamic theology, philosophy, history, journalism, and enlightenment. During those years he wrote a number of outstanding works, which became a significant phenomenon in the life of the Muslim world. During those years Musa Bigiev wrote a magnificent literary work understood by all educated Turks, his works easily crossed the borders of Russia and stirred public opinion among the population of the Ottoman Empire, suddenly becoming an object of universal attention.

Sadri Maksudi (1878-1957) is a graduate of the Sorbonne, deputy of the 3rd and 4th convocations of the State Duma of the Russian Empire, head of the National Autonomy of the Tatars of Russia, deputy of the Turkish parliament, adviser of Ataturk - the first President of Turkey, professor of Ankara and Istanbul universities, who made a great contribution to the development of legal science and legal institutions of Turkey, an active participant of the renewal and formation of the modern Turkish language.

The research, pedagogical and public work of Sadretdin Nizametdin oglu Maksudi Arsal in Turkey was during the reign of Mustafa Kemal Ataturk (1923-1938), Ismet Inenu (1938-1950) and Mahmoud Dzhelal Bayar (19501960). The scientific traditions acquired by him during his stay in Russia and in France determined the direction of his research. Proceedings of S. Maksudi "Lectures on the History of Turkic Law" ("Türk Hukuk Tarihi Dersleri" 1928), "General Fundamentals of Law" ("Hukukun Umumi Esasları" 1937), "Philosophy of Law" ("Hukukun Pozitif Felsefesi" 1937), "The General History of Law" ("Umumi Hukuk tarihi" 1941), "The History of Philosophy of Law" ("Hukuk Felsefesi Tarihi" 1946) talk about originality, deep intelligence, knowledge of the history of the Turks. In the listed works the facts that introduce the history of Turkic law are presented. The idea of creating legal state- 
hood, the importance of studying the history of the Turkic law dominated in his works. Studying the history of the Turkic law was a part of social history, it was aimed at comparing the values of legal communication in different cultures, while S. Maksudi in his works emphasized the existence of a legal system in the Turkic states since ancient times. The scientist noted that an important component of a person's culture is his legal culture, based on a humane and respectful attitude towards each other. He is also elected three times to the Great Turkish People's Assembly: from 1931 to 1939 he is elected twice as a deputy from the People's Republican Party; from 1950 to 1954 from the Democratic Party. In 1936 the Tatar activist as part of the Great Turkish People's Assembly delegation traveled to London and Glasgow, and in 1937 visited Czechoslovakia [2, p. 47]. S. Maksudi was a member of the Turkish delegation in the Assembly of the League of Nations, held in London in 1936, and also in Breslau in 1937, where the Turkish delegation took part in discussions and negotiations. In Turkey, towards the end of his political career, he began to adhere to the principles of democracy and hated dictatorship. He was one of the best public speakers of his time, took part in the work of the League of Nations, as well as in important events within the Turkish Republic. Sadri Maksudi left a bright mark in the history of the Turkish people as an ambitious, active, and forward looking politician.

We must admit that the Tatar intellectuals who emigrated or lived in Turkey for a certain period of time had a great influence on the formation of the national self-consciousness of the Turks, on their development as a nation, on shaping Turkey as a secular state. Some of them were even included in the inner circle of Kemal Ataturk, the first president of the Turkish Republic, worked as his advisers on cultural and political issues. Their authority and influence were significant not only in the political and administrative life of the country, but also in its scientific and educational areas.

\section{REFERENCES}

1. Akchura Yusuf. Yeni Türk Devletinin öncüleri - 1928 yıl yazılarl [The pioneers of the new Turkish State - 1928 writings]. 2nd edition. Ankara, Ministry of Culture Publ., 2001. 260 p. (In Turkish)

2. Battal-Taymas A. Iki Maksudiler [The Two Maksudis]. Istanbul, 1959. 71 p. (In Turkish)

3. Gaynetdinov R.B. Tyurko-tatarskaya politicheskaya emigratsiya nachalo XX veka [The Turko-Tatar political emigration at the beginning of the 20th century - the 30s]. Naberezhnye Chelny, The Kamskiy Publ. House, 1997. 159 p. (In Russian)

4. Galäü M. Bolganchık yıllar [Haze]. Kazan, Tatar Book Publ. House, 1976. 216 p. (In Tatar)

5. Zhorzhon F. Tyurkskiye intelligenty Rossii $v$ Ottomanskoy imperii $i$ ikh vliyaniye v epokhu mladoturkov [Türkic intellectuals of Russia in the Ottoman Empire and their influence in the era of the Young Turks]. Islam in the Tatar World: History 
Gaynanova M.R. Educational activity of Tatar intellectuals

in Turkey in the first half of the 20th century

and Modernity: Materials of the International Symposium, Kazan, April 29 - May 1, 1996. Kazan, 1997, pp. 191-197. (In Russian)

6. Iskhakov S.M. Yevropa i musul'mane iz Rossii: pervyy opyt sotrudnochestva $v$ nachale XX veka [Europe and Muslims from Russia: the first experience of cooperation in the early 20th century]. Yevropa (Varshava) - Europe (Warsaw), 2003, no. 3, pp. 111-112. (In Russian)

7. Karimi F. Istanbul mektuplarl [Istanbul Letters]. Orenburg, 1913. 414 p. (In Tatar)

8. Natsionalniy arkhiv Respubliki Tatarstan (NA RT) [The National Archive of the Republic of Tatarstan]. Fo. 2461. Op. 1. D. 44. (In Russian)

9. Sibgatullina A.T. Kontakty tyurok-musul'man Rossiyskoy i Osmanskoy imperii na rubezhe $X I X-X X v v$. [Contact Turkic Muslims of the Russian and Ottoman empires at the turn of the 19th-20th centuries]. Moscow, Institute of Oriental Studies, 2010. 264 p. (In Russian)

10. Khayrutdinov A. Vvedenie. Musa Bigiev. Izbrannye trudy [Musa Bigiev. Selected works]. Vol. 1. Kazan, 2005. 336 p. (In Russian)

11. Shenel Sh., Pulat H. Akyiğitzade Musa Bey ve metin gazetesi [Musa Bey Akyegetzade and the newspaper Metin]. Tarih Okulu Dergisi - Journal of History School, 2018. Mart. No. XXXIII, pp. 567-588. (In Turkish)

About the author: Milyausha R. Gaynanova is a Candidate of Science (History), Senior Research Fellow, Sh. Marjani Institute of History of the Tatarstan Academy of Sciences (7A, Baturin St., Kazan 420111, Russian Federation); mgaynanova@ gmail.com

\title{
ПРОСВЕТИТЕЛЬСКАЯ ДЕЯТЕЛЬНОСТЬ \\ ТАТАРСКИХ ИНТЕЛЛЕКТУАЛОВ В ТУРЦИИ \\ В ПЕРВОЙ ПОЛОВИНЕ ХХ В.
}

\author{
M.P. Гайнанова \\ Институт истории им. Ш. Марджани \\ Академии наук Республики Татарстан \\ Казань, Российская Федераичия \\ mgaynanova@gmail.com
}

Стамбул и Казань в начале XX в. являлись центрами образования тюркского мира, центрами формирования этнического, национального и общетюркского самосознания. Между этими городами существовали теснейшие идейные и культурные связи, которые выражались в постоянных контактах и обмене информацией через газетные и журнальные материалы. Надо признать, что татарские интеллектуалы, эмигрировавшие в Турцию, оказали большое влияние на формирование национального самосознания турок, на формирование их как нации, на образование Турции как светского государства. Некоторые из них были в близком окружении первого президента Турецкой республики Ататюрка, работали его советниками по культурным и политическим вопросам. Их вес и влияние были значи- 
тельными не только в политической и административной жизни страны, но и в ее научной и образовательной сферах. Уже после образования Турецкой Республики начинается строительство национальных, просветительских школ, издаются газеты и журналы, целью которых являлось рост национального самосознания турок.

В докладе раскрывается вопрос о просветительской деятельности татарских интеллектуалов в Турции в первой половине XX в.

Ключевые слова: Турция, татарские интеллектуалы, образование, культурные связи.

Для цитирования: Gaynanova M.R. Educational activity of Tatar intellectuals in Turkey in the first half of the 20th century // Историческая этнология. 2018. Т. 3, № 2. C. 267-274. DOI: 10.22378/he.2018-3-2.267-274

Сведения об авторе: Гайнанова Миляуша Рамилевна - кандидат исторических наук, старший научный сотрудник, Институт истории им. Ш. Марджани Академии наук Республики Татарстан (420111, ул. Батурина, 7А, Казань, Российская Федерация); mgaynanova@gmail.com 